DOI: 10.14720/aas.2016.107.2.16

Agrovoc descriptors: Ghana, farms, mechanization, farm equipment, rice, plant production, input-output analysis, productivity, farm structure, agricultural structure

Agris category code: f01, e14,e16

\title{
Effect of mechanisation use intensity on the productivity of rice farms in southern Ghana
}

\author{
Emmanuel K. APIORS ${ }^{1}$, John K. M. KUWORNU²*, George T-M. KWADZO ${ }^{1,3}$
}

Received June 28, 2016; accepted August 27, 2016.

Delo je prispelo 28. junija 2016, sprejeto 27. avgusta 2016.

\begin{abstract}
This study analysed the effect of farm mechanisation on productivity of rice farms in southern Ghana. The empirical results of the stochastic frontier model of primary data solicited from 360 rice farmers in southern Ghana revealed that land size cultivated, agrochemical expenditure, tillage intensity, threshing intensity, education and transportation intensity were significant factors that positively influenced partial factor productivity with respect to mechanisation. On the other hand, reaping intensity, over use of fertilizers, and age of farmers negatively influenced partial factor productivity with respect to mechanisation. These results have implications for capacity building and government support to increase productivity on rice farms.
\end{abstract}

Key words: mechanisation, productivity, rice farms, southern Ghana, stochastic frontier model

\section{IZVLEČEK}

\section{UČINEK INTENZIVNOSTI UPORABE MEHANIZACIJE NA PRODUKTIVNOST PRIDELAVE RIŽA V JUŽNI GANI}

Raziskava analizira učinek uporabe mehanizacije na produktivnost pridelave riža na izbranih kmetijah v južni Gani. Rezultati modela stohastične analize mejne funkcije podatkov anketiranja 360 pridelovalcev riža v južni Gani so pokazali, da imajo na produktivnost $\mathrm{v}$ povezavi $\mathrm{z}$ mehanizacijo značilen pozitiven vpliv naslednji dejavniki: velikost obdelovalne površine, obseg uporabe zaščitnih sredstev in gnojil, intenzivnost obdelave zemljišča, intenzivnost mlačve, izobrazba in intenzivnost transporta. Po drugi strani so intenzivnost žetve, prekomerna uporaba gnojil in starost kmetovalcev negativno vplivali na produktivnost $\mathrm{v}$ povezavi $\mathrm{z}$ mehanizacijo. Dobljeni rezultati so pomembni za ustvarjanje dodatnih kompetenc kmetov in pri vladni podpori za povečanje pridelave na kmetijah riža.

Ključne besede: mehanizacija, produktivnost, riževe farme, južna Gana, stohastični model analize mejne funkcije

\section{INTRODUCTION}

Rice has been consumed in Ghana for a long time. Rice consumption in Ghana is dated far back in the $17^{\text {th }}$ and $18^{\text {th }}$ century. Before 1920 , rice was grown mainly by women in Western region and the Volta region, and was used for performing rituals during festivals. In terms of being a major staple in the Ghanaian diet, it gained prominence since 1960. Over the past years, the per capita consumption of rice has increased steadily to $24 \mathrm{~kg}$ in 2010 . It is expected to hit $63 \mathrm{~kg}$ by 2018 due to rapid

\footnotetext{
Department of Agricultural Economics and Agribusiness, University of Ghana, Legon

2 Agribusiness Management, School of Environment, Resources and Development, Asian Institute of Technology, Pathum Thani 12120, Thailand. *Corresponding author: jkuwornu@gmail.com

3 Ministry of Food and Agriculture
}

This paper is part of an MPhil thesis supervised by John K. M. Kuwornu and George T-M. Kwadzo at the University of Ghana, Legon. 
population growth, urbanization and change in consumer habits (Ministry of Food and Agriculture, 2009). Annual rice production fluctuation ranges from 130,000 to 182,000 metric tons, the difference largely due to area cultivated per year. In Ghana, rice production systems are grouped into three major environments in accordance with the International Rice Research Institute: irrigated rice, rain fed low land rice and upland rice. Irrigated rice is grown on fully irrigated land in the form of flood in all seasons or partially irrigated during the wet season. These are usually capital intensive schemes developed by government. They are usually found on heavy clay soils like the vertisol which can hold surface water for a long time. Currently, cropping intensity for this system is two crops per year. Controlled flooding system is the practice on most government irrigation schemes and private commercial rice farms. High yielding exotic aromatic varieties such as 'Togo Marshall', 'Jasmine' and 'Get Three' are the common varieties grown. Rain fed lowland rice is usually at the valley bottoms with bunded fields. Such fields may have farmwater conservation facilities that traps run off whenever it rains. It may have two crops per year but mostly one crop per year. Rice output from these fields are sold primarily to households and also consumed during festivals, very little output is sold in the general open market. This system is common in the Northern Region of Ghana where most of the red rice is produced. Upland rice is grown on soils with good natural drainage on unbunded fields. Production depends on sufficient continuous natural rain during the wet season. This system has only one crop per year. It is prominent in forest zone, mountainous areas as well as on flatlands. It is practised in the Western Region and Northern parts of the Volta Region. Rice production and development on commercial basis received a major boost of government subsidy in the 1970s and 1980s. However, much of the anticipated results did not materialize due to political conditions, for example, the partial abolishing of controlled prices and the removal of subsidies during adoption of the Structural Adjustment Programme (SAP) in 1983 to revive Ghana's Economy (KranjackBerisavljevic et al., 2003).

One major way to improve yearly output of rice given the climatic conditions in Ghana is to increase cropping intensity. With available constant irrigation for 365 days per year and a 120 days variety, it is possible to increase crop intensity from two crops per year to five crops within two years, making it consistent with fully irrigated areas in Thailand (Tinsley, 2009). Increasing the level of mechanization is the key to reduce crop conversion time and thereby increasing crop intensity. The term "mechanisation" in agriculture is used to describe tools, implements and machinery applied to improving the productivity of farm labour and of land; it may use either human, animal or motorized power, or a combination of these (Sims \& Kienzle, 2006). In practice, it involves the provision and use of all form of mechanical assistance for agricultural production. Agricultural mechanisation leads to reduction in drudgery, increased input usage as result of increased cropping intensity, expansion in area cultivated as a result of higher labour productivity, efficient utilization of inputs, and timeliness of operations leading to higher productivity and income, and improved livelihood (Sims \& Kienzle, 2006).

Available data on rice productivity in Ghana revealed that between 2002 and 2010 average yield of rice was 1.7-2.4 Mt/Ha compared with achievable yield of $6.5 \mathrm{Mt} / \mathrm{Ha}$ (Ministry of Food and Agriculture, 2011). The objectives of this study were twofold. First, the study determined intensity of mechanisation on rice farms. Second, the study estimated the effect of mechanisation intensity on productivity of rice farms.

\section{MATERIALS AND METHODS}

\subsection{The study area, sampling and data}

The study covered two major rice growing districts in Southern Ghana; communities in and around Asutsuare in the Shai-Osudoku District in the
Greater Accra Region, and communities in and around Weta in the Ketu North District in the Volta Region of Ghana. Asutsuare has about 2,786 hectares of land under cultivation while Weta has about 880 hectares of land under rice cultivation. 
These districts were selected because government through the Irrigations Development Authority (IDA) has made substantial investment in developing irrigation infrastructure in these areas for rice production. Based on the farmer population in the respective districts, 254 farmers from Asutsuare area and 106 farmers from Weta area were interviewed, to give a total sample size of 360 farmers. The rice growing communities were selected purposively and respondents were randomly selected within each community. Crosssectional data for the 2012 major season at farm level were solicited from rice farmers using structured questionnaires.

\subsection{Sources of mechanisation services accessed by farmers}

Farmers were asked to identify sources of mechanisation whether farmer owned, private service providers, or government mechanisation centers. Descriptive statistics was used to describe the sources of access to mechanisation.

\subsection{Level of mechanisation accessed by farmers}

All the possible production activities from land preparation through to harvesting were listed and presented to the farmer. The procedure used by (Ghosh, 2010) was adopted for the analysis. An index based on farmers ownership pattern and use of modern rice cultivating implements like power tiller, planters, sprayers, and harvesters, for respective activities was used. The farmers' response to the use of these implements was coded into scores, 1 for ownership or hired usage of implement for an activity, and 0 otherwise. The total score calculated ranged from $0 \%$ to $100 \%$ depending on the number of production activities for which mechanisation was used in 2012 major season of production. If a farmer had a total calculated score of $50 \%$ and above then it means half or more of his/her production activities was based on mechanisation and a value of 1 is assigned to the farmer and 0 otherwise. Descriptive statistics was used to describe the levels observed.

\subsection{Determinants of mechanisation access and intensity on rice farms}

In addressing this objective, first an index of mechanisation was calculated for each farmer. The simple proportion as used by Owombo et al.,
(2012) for measuring adoption index was used. The mechanisation index $\left(I_{m}\right)$ is given as:

$I_{m}=\frac{n A_{m}}{T A}$

Where $n A_{m}$ is number of activities mechanized; $T A$ is total number of activities to be mechanized on the farm.

Taking into account varying number of plots and their sizes for each farmer, $I_{m}$ can further be specified as:

$I_{m}=\frac{n P_{m}}{T P} \times \frac{n A_{m}}{T A} \times \frac{Z_{m}}{T Z}$

Where: $\mathrm{I}_{m}$ is mechanisation intensity index; $n P_{m}$ is number of plots mechanized by a farmer; $T P$ is total number of plots; $n A_{m}$ is number of activities mechanized on each plot; $T A$ is total number of activities on the farm; $Z_{m}$ is size of plot mechanized (each plot); $T Z$ is total size of plots (overall).

Since farmer's access to farm mechanisation could be censored, double hurdle model was employed to examine determinants of mechanisation access and intensity (Wooldridge, 2002).

\subsection{Effect of mechanisation intensity on the productivity of rice farms}

Productivity can be explained as the amount of output that can be produced with a given amount of input over time (Perloff, 2004). Productivity may be measured in terms of single input (Single Factor Productivity or Partial Factor Productivity) or in terms of multiple inputs (Multiple Factor or Total Factor Productivity (Mbam \& Edeh, 2011). This study adopts the partial factor productivity approach to measure productivity of rice farms. According to Tinsley (2009), Ghana has a hot humid tropical climate with just about 12 hours of sunshine, but with warm night temperatures that promote respiration losses. Therefore, a frontier yield of 6-7 metric tonnes per hectare is optimum for rice production in Ghana.

Partial factor productivity contributes to total factor productivity (Greg \& Greene, 2007). Also, improved partial factor productivity leads to higher

Acta agriculturae Slovenica, 107 - 2, september 2016 
aggregate output and at constant prices translate into higher income for farmers and improved livelihoods. These imply that indicators of partial factor productivity provide a useful insight into the success of policy reforms.

\subsubsection{Empirical specification of the stochastic frontier model}

The stochastic frontier model for estimating farm level technical efficiency was applied but with a particular focus on the contribution of intensity of mechanisation to rice productivity.

Kumbhakar (2002), Hang \& Liu (1994) and Reifscheider \& Stevenson (1991) have suggested stochastic production models capable of estimating the stochastic production function and the inefficiency function at the same time while using cross-sectional data. Battese \& Coelli (1995) proposed a model that is similar to Hang and Liu but specified for panel data. In recent empirical studies, the model formulated by Battese \& Coelli (1995) is specified in the cross-sectional analysis.

Following Obi \& Chiasngo (2011) the functional form used in this paper is the Cobb-Douglas specification because it is flexible and very convenient for estimating technical efficiency. In this paper, mechanisation is represented by capital. The generalized Cobb-Douglas model is given as:

$$
Q=A L^{\alpha} K^{\beta}
$$

Where $\mathrm{Q}$ is output; $L$ is labour; $\mathrm{K}$ is capital; $A, \alpha, \beta$ are constants. Land and capital could be interchanged and $Q$ will be unaffected. Alternatively, the model can be stated as:

$$
P(L, K)=b L^{\alpha} K^{\beta}
$$

Where $P$ denotes total production (monetary value of all output produced within a period); $L$ denotes labor input (total man-hours within a period quantified in monetary terms); $K$ denotes capital input (monetary value of machinery, equipment, and buildings); $b$ denotes productivity (total factor or partial factor); the terms $\alpha$ and $\beta$ are the output elasticities of labor and capital, respectively. These values are constants determined by intensity of mechanisation. The output elasticities $\alpha$ and $\beta$ measure the degree of responsiveness of output to a change in levels of either labor or capital used in production, ceteris paribus.

The stochastic frontier function is specified in equation (5) as follows:

$$
\operatorname{Ln} Y_{i}=\operatorname{Lnf}\left(x_{i} ; \beta\right)+\exp \left(v_{i}-u_{i}\right)
$$

$Y_{i}$ is the production (output) of the $i^{\text {th }}$ farmer; $X$ is a vector of input quantities from the $i^{\text {th }}$ farmer; $\beta$ is a vector of parameters to be estimated; $V_{i}-U_{i}$ constitutes the disturbance (error) term. Given the above, the next step is to estimate the partial factor productivity due to mechanisation. Partial Factor Productivity is the ratio of output to a single input. The logarithmic Cobb Douglas specification of the partial factor productivity $\left(P F P_{M}\right)$ due to mechanisation is specified as:

$\ln P F M_{i}=\beta_{0}+\beta_{1} \ln$ Till $+\beta_{3} \ln$ Irrig $+\beta_{4} \ln \operatorname{Re}_{p_{i}}+\beta_{5} \ln$ Thresh $+\beta_{5} \ln$ Transp + $\beta_{6} \ln$ Winow $+\beta_{7} \ln$ Land $+\beta_{8}$ Lab $+\beta_{9} \ln$ Seed $+\beta_{10} \ln$ Fert $+\beta_{11} \ln$ Agrochemt $\beta_{12} \ln$ Creditamt $\beta_{13} \ln N$ Fincomet $\beta_{14} \ln$ Extcont $_{i}+\beta_{15} \ln$ Aget $\beta_{16} \ln$ Exp $_{i}+$ $\beta_{17}$ Gend $+\beta_{18} \ln E d u_{i}+\beta_{19} L o c_{i}+\left(V_{i}-U_{i}\right)$

Where $P F P_{i}$ is Partial factor productivity (value of output/value of mechanisation input) in 2012 major season, $\beta_{\mathrm{i}}$ 's are elasticities, $i$ refer to the $i^{\text {th }}$ farmer and $L n$ is the natural logarithm operator; $U_{\mathrm{i}}$ is errors due to farmer inefficiency and $V_{i}$ are errors due to factors outside farmers control. It is worthy to note that the gender and location variables were not log transformed because they were dummy variables. This is a hybrid form of the log-linear transformation of the Cobb Douglas production function.

2.5.2 Description of variables for the stochastic frontier model

The descriptions, measurements and hypothesized relationships of the independent variables with the dependent variable (i.e. partial factor productivity) are presented in Table 1. 
Table 1: Description of variables, measurements and hypothesized relationships for the stochastic frontier model

\begin{tabular}{|c|c|c|c|}
\hline Variable & Description & Measurement & $\begin{array}{l}\text { Hypothesized } \\
\text { relationship }\end{array}$ \\
\hline \multicolumn{4}{|l|}{ Dependent } \\
\hline $\mathrm{PFP}_{\mathrm{M}}$ & $\begin{array}{l}\text { Value of output/value of } \\
\text { mechanisation used }\end{array}$ & Ghana Cedis (GHS) & \\
\hline \multicolumn{4}{|c|}{ Independent } \\
\hline Till & Tillage & Intensity Index & + \\
\hline Irrig & Irrigation & Intensity Index & + \\
\hline Reap & Reaping (harvesting) & Intensity Index & + \\
\hline Transp & Transportation & Intensity Index & + \\
\hline Winow & Winnowing & Intensity index & + \\
\hline Land & Cultivated land area & Hectares & + \\
\hline $\mathrm{Lab}$ & Labour expenditure & GHS & + \\
\hline Seed & Improved seed expenditure & GHS & + \\
\hline Fert & Fertilizer expenditure & GHS & + \\
\hline Agro & Agro chemicals expenditure & GHS & + \\
\hline Credit & Amount of credit & GHS & + \\
\hline NF income & Non-farm income & GHS & + \\
\hline Ext & Extension visit per year & Number of contacts & + \\
\hline Age & Age of farmer & Completed Years & + \\
\hline Gend & Gender of farmer & $\begin{array}{l}\text { Dummy (Male }=1 \text {, Female } \\
=0)\end{array}$ & $+/-$ \\
\hline Educ & Formal education & Years & + \\
\hline Exp & Years in rice farming & Years & + \\
\hline Loc & Location & $\begin{array}{l}\text { Dummy (Asutsuare }=1 \text {, } \\
\text { otherwise }=0 \text { ) }\end{array}$ & $+/-$ \\
\hline
\end{tabular}

Tillage intensity index: This variable indicates the proportion of total land size cultivated that was tilled using either tractor, power tiller or both. It is a continuous variable. It is hypothesized that increased tillage intensity results in higher productivity (Nandal \& Rai, 1986; Tinsley, 2009).

Irrigation intensity index: This variable indicates proportion of cultivated land that was irrigated because irrigation is a mechanisation process (Ghosh, 2010). It is a continuous variable. It is hypothesized that the size of land irrigated contributes positively to physical output of yield and hence productivity. Water is retained within root zones of plant on irrigated farms. This enables plant to utilize the water in time of need. Irrigation intensity improves cropping intensity and contributes positively to the productivity of available land (Reardon et al., 1996; Bhattarai et al., 2002).

Reaping (harvesting) intensity index: This is variable indicates the proportion of rice farm that was harvested using motorized rice reaper (cutter) or combined harvester. Under good soil conditions using machines to harvest rice reduces drudgery, improves efficiency of labour, reduce harvesting wastage, and hence, positively influences rice productivity (Mahrouf \& Rafeek, 2003; Tinsely, 2009).

Threshing intensity index: This variable represents the proportion of the rice farms that was threshed using combine thresher or stationary motor powered thresher, just as mechanized reaping, using machine to thresh harvested paddy contributes positively to productivity (Mahrouf \& Rafeek, 2003; Tinsely, 2009).

Transportation intensity index: This variable measures the proportion of the cultivated farm produce that was transported using automobile vehicle for example, tractor, power tiller, or any motor powered truck. The mode of transporting the harvested produce from the field to the drying floor could cause wastage of the paddy, or delays on the field which may cause paddy to deteriorate. It is hypothesized that increase intensity of 
transportation is positively related to the quality and quantity of rice output and hence, productivity.

Winnowing intensity: This variable measures the extent to which motorized equipment is used to clean the harvested rice paddy on the drying floor. It is a continuous variable and it is hypothesized that increased intensity of winnowing will influence productivity of rice positively.

Land: This variable indicates the size of farm land cultivated in hectares. Larger land sizes may improve rice yield per hectare and hence, productivity of the land is effectively utilized (Binswinger 1978ab; Bagyo \& Lingard, 1983; Foster \& Rosenzweig, 2011).

Labour: This variable indicates expenditure on labour used (GHS). Expenditure on labour influences productivity with respect to mechanisation. Studies indicate that increases in intensity of mechanisation is associated with increase in labour expenditure due to larger area cultivated and also employment of skilled labour to operate the machinery (Balishter \& Singh, 1991; Verma, 2008).

Fertilizer expenditure: This variable represents fertilizer use intensity. It is established that the use of fertilize is positively related to productivity (Reardon et al., 1996). It is expected that fertilizer usage to the optimum recommended level is positively related to productivity and vice versa.

Amount of institutional credit: Access to institutional credit enables the farmer to purchase mechanisation equipment with ease or afford available mechanized services which translate into higher productivity. Nakano \& Kajisa (2011) suggest that access to credit improves timely purchase of fertilizer and agrochemical hence, positively related to productivity. It is therefore intuitive that increase in the amount of credit received will increase productivity.

Nonfarm income: This variable represents the amount of non-farm income received by the farmer during the season under study. Mechanisation equipment is capital intensive and requires substantial cash resources. Reardon et al., (1996) suggest that non-farm income contributes positively to acquisition of farm machinery and positively relates to productivity of farms.

Improved Seed Expenditure: This variable indicates hybrid seeds or improved variety and the amount of expenditure made on improved seed. It is hypothesized that farmers who use adequate quantities of improved varieties are more likely to achieve higher levels of productivity. The optimum quantity of seed for transplanting and broadcasting is $75 \mathrm{~kg}$ per hectare and $100 \mathrm{~kg}$ per hectare, respectively. Inadequate seed input is less likely to achieve higher productivity (Obi \& Chisango, 2011).

Total physical output of rice: At the same input level and land size, the higher the physical output the higher the productivity and the income, all things being equal.

Age: This variable measures age of household head in years. Older farmers may have enough wealth due to longer periods of saving and better network. These enable easy access to resources compared to younger farmers. It is hypothesized that age is positively correlated to machinery access, and higher productivity (Mushunje et al., 2003).

Chemicals Expenditure: This variable measures the intensity of herbicides and pesticide usage (value of total amount spent in (GHS). It is hypothesized that farmers with efficient and controlled usage of herbicides and pesticides will attain higher yield. Agrochemicals are complimentary input and hence influence productivity positively (Nakano \& Kajisa, 2011).

Number of contacts with extension agent: This is measured by frequency of contacts made with extension agent either by visitation or during training sections. Frequent contact with extension agents may provide the farmer with information on new technologies for farming and how to access the technologies. It is hypothesized that higher number of contacts with the extension agents will correlate positively with access to improved technology which will translate into higher productivity.

Gender of farmer: This variable indicates the sex of the respondent. This is a dummy variable 
$(1=$ Male, $0=$ Female $)$. Gender could be positively or negatively related to productivity.

Education level of farmer: This is measured by the number of years in formal education. It is expected that higher years of formal education will positively correlate with mechanisation and hence productivity.

Experience of farmer: Number of years in farming could influence farmers to employ more labour saving technologies in carrying out activities on the farm to improve productivity.

Location: This variable indicates the location of the farmer. It is represented by a dummy ( 1 = Asutsuare, and 0 otherwise). There could be differences in productivity due to geographical location as a result of soil characteristics or precipitation. This may influence productivity positively or negatively.

\section{RESULTS AND DISCUSSION}

\subsection{Level of mechanisation use intensity by farmers in the production cycle}

Eleven activities or operations in the rice paddy production process required mechanisation. The number of activities mechanised indicates the operations for which motorised equipment was used. The level of mechanisation achieved indicates the proportion of activities mechanised. The minimum number of activities mechanised was 1 (one); with a corresponding level of mechanisation achieved being $9.0 \%$. About $4.4 \%$ of farmers achieved the minimum level of mechanisation. All the respondents were able to access machinery to mechanise at least one activity in the paddy production process. The maximum number of activities mechanised was six (6), with a corresponding level of mechanisation being $55 \%$. About $26.4 \%$ of respondents achieved $55 \%$ mechanisation in the rice production process. A relatively higher proportion of respondents $(47.2 \%)$ mechanised four activities in the paddy production process representing $36.0 \%$ level of mechanisation. It appeared that this level was considerably low to cause appreciable level of increased productivity.

\subsection{Effect of mechanisation intensity on the productivity of rice}

The empirical results of partial factor productivity of rice farms with respect to mechanisation intensity are presented in Table 2 . Since both side of the partial factor productivity equation are logged, the results could be discussed in terms of percentages (elasticities). The results of the stochastic frontier estimates indicated that tillage intensity, threshing intensity, transportation intensity, land size cultivated, agrochemical expenditure, and gender were positively related to partial factor productivity of rice with respect to mechanization. In this regard, land size had the greatest positive influence on rice productivity, followed by tillage intensity, transportation intensity, threshing intensity, agrochemical usage and experience. 
Table 2: The effect of activity specific mechanisation intensity on partial factor productivity

\begin{tabular}{llll}
\hline Stochastic frontier normal/exponential model & & \\
\hline Ln_PFP & Coef. & Std. Err. & P>z \\
LnTil & $.3212^{* * *}$ & .0581 & 0.000 \\
LnIrr & -.0346 & .0237 & 0.146 \\
LnReap & $-.1204^{* *}$ & .0480 & 0.012 \\
LnThresh & $.0934^{* *}$ & .0487 & 0.055 \\
LnTrans & $.1836^{* * *}$ & .0472 & 0.000 \\
LnWinow & .0126 & .0284 & 0.656 \\
LnLand & $.3757^{* * *}$ & .0900 & 0.000 \\
LnLab & .0073 & .0466 & 0.874 \\
Lnseed & -.0088 & .0407 & 0.827 \\
Lnfert & $-.1834^{* * *}$ & .0616 & 0.003 \\
LnAgrochem & $.0822^{* *}$ & .0363 & 0.024 \\
Credit amt. & & & \\
NF Income & -.0000 & .0001 & 0.578 \\
Ext contact & -.0002 & .0001 & 0.112 \\
Age & -.1936 & .1294 & 0.135 \\
Experience & $.05180^{* * *}$ & .0185 & 0.005 \\
Gender & -.0081 & .0209 & 0.698 \\
Edu (yrs) & -.2892 & .3554 & 0.416 \\
Loc & $-.0774^{* *}$ & .0410 & 0.059 \\
cons & .1485 & .1189 & 0.212 \\
& -3.6689 & .9229 & 0.000
\end{tabular}

Observations (N) 360

Prob $>$ chi Squared 0.0000

Log likelihood $\quad-142.5860$

Wald chi Squared 77.40

Significant denoted as *** (1\%), ** (5\%) and *(10\%)

Source: Authors' computation from field data, 2012

Tillage Intensity: The coefficient of tillage intensity was positive and significant at 1 percent significance level, contributing to productivity with respect to mechanisation. An increase in the intensity index of tillage will cause productivity with respect to mechanisation to increase by 32 percent and vice versa. Mechanized tillage is laborsaving (Binswinger, 1978ab) and promotes cultivation of larger land sizes. Seedling root establishment is related to how well the soil is cultivated and this increases productivity (Tinsley, 2009).

Reaping (Harvesting) intensity: This variable was significant at 5 percent but negatively contributes to productivity. An increase in reaping (harvesting) intensity index will cause partial factor productivity with respect to mechanisation to decrease by 12 percent. The result of reaping intensity is contrary to the expected hypothesized relationship. This could be attributed to the following reasons: First, the rice reaping machines (harvesters) operate well under specific conditions. It could be that the harvesters being used were not operating well because of suboptimal field conditions. Field conditions such as soil moisture condition, weed population, plot size, maturity of rice, crop density, lodging and operator skills affect performance of harvesting (Mahrouf \& Rafeek, 2003). Low performance levels of harvesting machinery as a result of suboptimal field conditions could result in low physical output of paddy rice, hence, translating into a low productivity with respect mechanisation. Secondly, the entry of rice harvesting machinery unto the irrigated rice farm depends on the wet and sticky or dry nature of the soils (Mahrouf \& Rafeek, 2003). This is influenced by the predominant soil series on a particular rice farm. Soils which are light and less sticky (loamy) with relative amount of sand are quick to dry and are compatible with rice harvesting machinery better than heavy soils 
(vertisol). For example, the Akuse series (vertisol), records higher physical output of paddy than the Amo series (loam). Therefore, it is possible that the soils on the farms on which mechanised reaping of rice was done have low productivity of rice due to their physical, chemical and biochemical properties.

Threshing intensity index: This variable contributes positively to productivity of rice farms and was significant at 10 percent. An increase in the intensity index of threshing will lead to an increase in the productivity of rice farm with respect to mechanisation and vice versa.

Transportation intensity index: This variable was significant at 1 percent and positively related to the productivity of rice farms.

Land size cultivated was significant at 1 percent and positively contributes to partial factor productivity of rice farms with respect to mechanisation. This is due to the fact that as cultivated land area increases, higher demand is made on the amount of labour used, hence, the need to replace labour with machinery, and this increases productivity. This finding is consistent with land size cultivated having the greatest influence on yield (Bagyo \& Lingard 1983); and farm mechanisation is being most profitable where land is relatively abundant (Binswinger 1978ab).

The expenditure on fertilizer purchased was significant at 1 percent but contributes negatively to the productivity of rice farms. This result could be due to the fact that farmers are applying quantities of fertilizer above the recommended quantities on their fields. This is negatively affecting the output of rice. Gebrekidan \& Seyoum (2006) revealed that overdose application of fertilizer on rice in flooded vertisols has a negative effect on rice yield.

Expenditure on agrochemical used was significant at 5 percent and contributes positively to the productivity of rice farms. A cedi increase in agrochemical expenditure will cause productivity due to mechanisation to increase by 8 percent. This could be explained by the fact that agrochemical usage complements cultivation of larger farm sizes and promotes substitution of labour with machinery, which could translate to higher productivity. The usage of agrochemical is a component of mechanisation in total (Obi \& Chisango, 2011).

selective medium. Out of them, 9 or $5.4 \%$ grew successfully, while 5 or $3 \%$ failed (Tables 3 and 4). The age of farmers was significant at $1 \%$ percent. Age variable contributes to inefficiency of farmers with respect to mechanisation.

Number of years of education was significant at 5 percent and negatively influences inefficiency of mechanisation in rice farms. This indicates that increased number of years in formal education reduced farmer's inefficiency, and therefore, contributes positively to productivity. This could be attributed to the fact that as farmers spend more years on formal education they turn to adopt technologies that in turn reduce inefficiency. This result is somewhat consistent with Corner-Thomas et al. (2015) that education of the farmer positively influences the use farm management tools that results in increase productivity.

The results of the study revealed that the major source of machinery service provision was private service providers for all activities that used mechanization except in the case of irrigation where government is the major service provider. This implies that rice farmers rely on private service providers for their mechanisation service on the farm because mechanisation services from government is either unavailable or inadequate. However, these private service providers are not necessarily those supported under public private partnerships. Furthermore, results revealed that government is the dominant service provider for irrigation on the rice farms. This means that prospective rice farmers who are interested in cultivating irrigated rice would have to rely on government for infrastructural support and service.

The findings suggested that farms with higher intensity of mechanisation had increased productivity compared to farms with low intensity of mechanisation.

Farmers' decision to mechanise operations on rice farms is limited by unavailability of machinery for mechanising some specific activities. Farms with available machinery service centre in their communities are more likely to mechanise 
activities on the rice farms because of greater access. This means that developing the capacity of machinery service providers to establish service centers within relatively shorter distances to farms will improve mechanisation of activities on the rice farms and hence increase productivity.

The higher the access to credit, non-farm income and returns from rice farms, the more activities that will be mechanised on the rice farms. Therefore attempts to improve credit access, increase nonfarm income or returns from rice will raise rice productivity.

Land owners are less likely to intensify mechanisation use because of relatively smaller land holdings. Therefore policies aimed at developing capacity of farmers to enable farmers own larger lands and farms will promote mechanised farming and increased productivity of rice.

Increased usage of agrochemical and increased investment in skilled labour compliment mechanisation and cultivation of larger areas. These contribute to higher access to mechanised farming, increased mechanisation intensity and higher productivity of rice farms.

Planting improved seed quantities as well as applying fertilizer quantities above the recommended rate reduces productivity with respect to mechanisation. Therefore, it is important that farmers are educated on the need to avoid excessive sowing of seeds and misapplication of fertilizers.

Farmers who cultivate larger land size have greater access to mechanisation and higher productivity of rice. This implies that policies targeted to support land consolidation and development in order to expand farms cultivated will increase productivity of rice.

Farmers who intensify their use of machinery for land preparation are more likely to achieve higher productivity than farmers who do not mechanize tillage. This means that policies aimed at developing farmers' capacity in order to intensify mechanized tillage will improve rice productivity.

The results also indicated that farmers who mechanized threshing and transportation of paddy rice are more productive with respect to mechanisation than those who do manual threshing and transportation.

To ensure that mechanised reaping (harvesting) of rice improves productivity, the crops must not be logged and the soil must possess good easily drying characteristics to enable access of the machinery unto the field. This implies that soil management practices that promote productivity of soil and optimum environment for reaping machines to work will improve rice productivity.

Experienced farmers turn to intensify mechanisation to a higher extent as compared to less experienced farmers. In other words, experienced farmers are more productive in the use of mechanisation than less experienced farmers.

Rice farmers with smaller household size were more likely to intensify the use of mechanisation and hence, were more productive with respect to mechanisation as compared to farmers with bigger household sizes.

Male farmers and younger farmers have a higher chance of accessing machinery and hence were more productive with respect to mechanisation.

Reaping (harvesting) intensity is negatively related to partial factor productivity of rice with respect to mechanisation. However, this could largely be attributed to the fact that some reaping machines do not operate well in small, wet, weedy fields, muddy fields or when crops are logged. Also, it could be partly due to variations in rice yields as a result of soil series variations in the study area. For instance, the Akuse series (the soil series in ShaiOsudoku area) is observed to contribute to higher yields of rice compared to the Amo series (the soil series in Ketu North District). However, mechanisation is more difficult on the Akuse series compared to the Amo series. 


\section{CONCLUSIONS AND IMPLICATIONS}

First, the study has implications for capacity building. The number of years of education negatively influences inefficiency of mechanisation in rice farms. This indicates that increased number of years of formal education reduced farmer's inefficiency, and therefore, contributes positively to productivity. This could be attributed to the fact that as farmers spend more years on formal education they turn to adopt technologies that in turn reduce inefficiency. The Agricultural Extension Agents could educate the farmers on optimum quantities of mechanized services to utilise as well as improved seed and fertilizers rate per hectare to increase productivity. Also, increasing agrochemical usage and investment in skilled labour positively influenced rice productivity. It is recommended that farmers should explore application of agrochemical and more use of skilled labour to expand area cultivated. This will improve productivity of rice farms with respect to mechanisation. Furthermore, farmers should be educated to practice good management of soils conditions to provide optimum crop environment for harvesters to work; this will ensure that increased usage of reaping (harvesting) machines will increase the productivity of rice farms.

Second, the results have implications for government support in order for the rice farmers to increase productivity. Thus, to increase rice productivity farmers should increase the use of machines for tillage, threshing and transportation of paddy in order to increase rice productivity. Government can facilitate this process by proposing ways by which the farmers can acquire power tillers, cutters, threshers, and tractors for farming. The results suggest that private service providers dominate the delivery of mechanisation service to rice farmers. It is imperative that the capacity of private service providers be developed through government assistance to enable them acquire and set up mechanisation service centres that are close to the rice farms. This will make farm machinery and equipment available to enable easy access for rice farming. Further, it is critical that government continues to fast track the implementation of massive irrigation infrastructure development such as the proposed Accra plains development project which potentially will enable farmers a bigger access to irrigated land and modernized agriculture.

Finally, businessmen interested in investing in mechanized service provision should expand their services to activities such as transplanting, insect control, weed control, fertilizer application and drying. These will increase farmers' level of mechanisation for higher productivity. Rice farmers should avoid excessive use of seed quantities and fertilizers because these practices turn to reduce access to mechanisation (through probably spending their incomes unnecessarily on these inputs), thereby negatively influencing rice productivity. Credit institutions should consider the timely need of credit by farmers, in responding to providing credit to farmers. This will enable the farmers utilize the credit to serve its intended purpose in improving productivity. Rice income and non-farm income improved mechanisation intensity. Therefore, rice farmers should expand their alternative sources of income; this will promote intensification of mechanisation on rice farms for increased productivity.

\section{REFERENCES}

Bagyo, A. S., Lingard, J. (1983). The Impact of Agricultural Mechanisation on Production and Employment: The Consequences of Small Rice Farm Mechanisation Project. USAID, IRRI and Agricultural Development Council Inc.

Balishter, G. V. K., Singh, R. (1991). Impact of Mechanisation on Employment and Farm Productivity. Productivity 32(3): 484-489.
Battese, G. E., Coelli, T. J. (1995). A model for technical efficiency effects in a stochastic frontier production functions for panel data. Empirical Economics, 20: 325-332. Doi: 10.1007/BF01205442

Bhattarai, M., Sakthivadivel, R., Hussain, I. (2002). Irrigation impacts on income inequality and poverty alleviation: Policy issues and options for improved management of irrigation systems. Working Paper

Acta agriculturae Slovenica, 107 - 2, september 2016 
39. Colombo, Sri Lanka: International Water Management Institute.

Binswanger, H. P. (1978a). Agricultural Mechanization: A Comparative Historical Perspective, University of Oxford, UK.

Binswanger, H. P. (1978b). The Economics of Tractors in South Asia: An Analytical Review Agricultural Development Council, New York and International Crops Research Institute for the Semi-arid Tropics, Hyderabad, India.

Corner-Thomas, R. A., Kenyon, P. R., Morris, S. T., Ridler, A. L., Hickson, R. E., Greer, A. W., Logan, C. M., Blair, H. T. (2015). Influence of demographic factors on the use of farm management tools by New Zealand farmers. New Zealand Journal of Agricultural Research, 58(4): 412-422. Doi: 10.1080/00288233.2015.1063513

Foster, A D., Rosenzweig, M. R. (2011): Are Indian Farms Too Small? Mechanisation, Agency Costs and Farm Efficiency. Brown University.

Gebrekidan, H., Seyoum, M. (2006). Effects of Mineral $\mathrm{N}$ and $\mathrm{P}$ Fertilizers on Yield and Yield Components of Flooded Lowland Rice on Vertisols of Fogera Plain, Ethiopia. Journal of Agriculture and Rural Development in the Tropics and Subtropics, 107(2): 161-176.

Ghosh, B. K. (2010). Determinants of Farm Mechanisation in Modern Agriculture: A Case Study of the Burdwan District of West Bengal. International Journal of Agricultural Research, 5(12):1107-1115.

Doi: 10.3923/ijar.2010.1107.1115

Greg, H., Greene, H. (2007). Assessing the impact of competition Policy Reforms on Australia's Infrastructural Performance. A report for the Australian Competition and Consumer Commission. NERA Economic Consulting; Mash and Mclennan companies, Sydney.

Hang, C.J., Liu, J. T. (1994). A non-neutral stochastic frontier production function. Journal of Productivity Analysis, 5: 171-180. Doi: 10.1007/BF01073853

Kumbhakar, S.C. (2002). Specification and estimation of production risk, risk preference with flexible risk properties. Journal of Productivity Analysis, 8: 269280.

Kranjack-Berisavljevic, G., Blench R. M., Chapman R, (2003). Rice Production and Livelihood in Ghana, Multi-Agency Partnership (MAP) for Technical Change in West African Agriculture.
Mahrouf, A. R. M., Rafeek, M. I. M. (2003). Mechanisation of paddy harvesting: the economic perspective. Annals of the Sri Lanka Department of Agriculture 5: 161-172.

Mbam, I.B.N., Edeh, H.O. (2011). Determinants of farm productivity among smallholder rice farmers in Anambra State, Nigeria. Journal of Animal \& Plant Sciences, 9 (3): 1187- 1191.

Ministry of Food and Agriculture (2009). National Rice Development Strategy (Draft), SRID, Accra.

Ministry of Food and Agriculture (2011). Agriculture in Ghana. Facts and Figures 2010, SRID, Accra.

Mushunje, A., Belete, A., Fraser, G.C.G. (2003). Technical Efficiency of Resettlement Farmers of Zimbabwe. Contributed Paper Presented at the $41^{\text {st }}$ Annual Conference of the Agricultural Economics Association of South Africa (AEASA), October 2-3, 2003, Pretoria, South Africa.

Nakano, Y., Kajisa, K. (2011). The Impact of Access to Credit and Training on Technology Adoption: A Case of the Rice Sector in Tanzania. Selected paper prepared for presentation at the Agricultural \& Applied Economics Association's, AAEA \& NAREA Joint Annual Meeting, Pittsburgh, Pennsylvania.

Nandal, D.S., Rai, K. N. (1986). Impact of Farm Mechanisation on Farm Productivity in Haryana.

Obi, A., Chisango F. (2011). Performance of Smallholder Agriculture under Limited Mechanisation and the Fast Track Land Reform Program in Zimbabwe. International Food and Agribusiness Management Review, 14(4), 85-104.

Owombo, P.T., Akinola A.A., Ayodele O.O., Koyedole, G. F. (2012). Economic Impact of Agricultural Mechanisation Adoption: Evidence from maize farmers in Ondo State Nigeria. Journal of Agricultural and Biodiversity Research, 1(2): 2532.

Perloff, M. J. (2004). Microeconomics. Third Edition. Pearson Educational Inc. pp. 517-527.

Reardon, T., Kelly, V., Crawford, E., Jayne, T., Savadogo, K., Clay, D. (1996). Determinants of Farm Productivity in Africa: a Synthesis of Four Case Studies. Policy Synthesis for Cooperating USAID Offices and Country Missions.

Reifscheider, D., Stevenson, R. (1991). Systemic departure from the frontier: a framework for the analysis of firms efficiency. International Economic Review, 32: 715-723. 10.2307/2527115

Sims, B. G., Kienzle, J. (2006). Farm power and mechanisation for small farms in sub Saharan 
Africa, Agricultural and Food Engineering Verma, S.R. (2008). Impact of Agricultural Technical Report. Food and Agriculture Mechanisation on Production, Productivity, Organisation of the United Nations, Rome.

Tinsley, R. (2009). Increasing Rice Productivity for the Kpong Irrigation Project Akuse-Asutsuare, Ghana: Farmer-to-Farmer Program. Consultant Report ACDI/VOCA, Accra, Ghana. Cropping Intensity, Income Generation and Employment of Labour: Status of Farm Mechanisation in India. Punjab Agricultural University, Ludhiana, pp. 133-153.

Wooldridge, J. (2002). Econometric Analysis of Cross Section and Panel Data, Cambridge: MIT Press. 